\title{
GEOCHEMICAL CHARACTERIZATION OF BANANA, BURITI PALM, JUTE AND COIR FIBRES FOR USE AS BIOGEOTEXTILES FOR EROSION CONTROL
}

\author{
Charles Izuchukwu EGBUJUO ${ }^{*}$, Michael A. FULLEN ${ }^{1}$, Antonio J. T. GUERRA², \\ Alexander Iheanyi OPARA ${ }^{3}$ \\ ${ }^{1}$ Faculty of Science and Engineering, University of Wolverhampton, Wolverhampton WV1 1LY, United Kingdom \\ ${ }^{2}$ Department of Geography, Federal University of Rio de Janeiro, Ilha do Fundão, Rio de Janeiro, Brazil \\ ${ }^{3}$ Department of Geosciences, School of Science, Federal University of Technology, PMB 1526 Owerri, Nigeria
}

Received 18 January 2017; accepted 14 December 2017

\begin{abstract}
Geochemical analysis of selected plant fibres used as geotextiles for erosion control was conducted to evaluate their geochemical composition and to determine the elements that could potentially be nutrients for plants or cause heavy metal contamination in soils. Analysis of the samples was performed using X-ray Diffraction and X-ray Fluorescence spectrometry. Results revealed that potassium concentrations varied from $3.63 \%$ in jute-mat (India) $-50.73 \%$ in bananaleaf (São Romão, Brazil), with a mean of $27.17 \%$. Similarly, calcium concentrations varied from $0.09 \%$ in banana-leaf (São Romão) $-37.0 \%$ in banana-leaf/stem (Oleo, Brazil). Iron concentrations varied from $0.15 \%$ in banana-leaf/stem samples (Oleo) $-4.47 \%$ in jute-cloth (India). Since banana-leaf/stem had the highest concentration of macro-nutrients, it is therefore proposed that banana-leaf has the highest potential for adding nutrients to the soil system when biodegraded. In addition, heavy metal analysis of the samples revealed that none of the fibres have high concentrations that may contaminate the soil upon decomposition.
\end{abstract}

Keywords: landscape management, biogeotextiles, geochemical characterization, X-ray fluorescence spectrometry, macronutrients, micro-nutrients, heavy metals.

\section{Introduction}

Land degradation may occur through the collective effects of pressures on land due to rapid population growth and urbanization, ecological problems associated with climate change, improper and unsustainable land use and other land management policies. Substantial land use changes in these areas have therefore led to the transformation of native vegetation to pasture, agriculture and other developmental purposes (Carvalho et al. 2010). Soil erosion is a major environmental issue threatening ecosystems in many areas of South America, Asia and Sub-Saharan Africa and indeed world-wide. It is estimated that worldwide, 5-7 million hectares of farmland are lost annually due to soil erosion and other forms of land degradation (FAO 2017). Gully erosion is a highly visible form of soil erosion that affects soil productivity, restricts land use and can threaten the integrity of infrastructures. It generally results in the siltation of waterways, dams and reservoirs. Suspended sediments, which may have absorbed nutrients and pesticides, can adversely affect surface water quality. These fine colloidal clay particles most often remain in suspension and may pollute both surface- and groundwater and damage aquatic ecosystems.

Controlling gully erosion can be problematic. A mature vegetative cover of thick and uniform turf usually has the ability to substantially decrease soil erosion compared with bare soil (Rickson 2006; Guerra et al. 2010, 2015, 2017). However, establishing mature vegetation can take some time, thus posing a high risk of erosion during the vegetation establishment phase, as the plant canopy, stems and roots will be undeveloped and thus unable to prevent soil erosion (Bhattacharyya et al. 2010a). Therefore, in the absence of instant and suitable plant shields, hill-slopes often experience severe soil erosion. The use of geotextiles for erosion control offers suitable and instant soil protection within the growth developmental stages from germination to complete maturity of suitable plant shields (Rickson 2006; Tapobrata 2017). When geotextiles are emplaced, they can last in a specific area for a long

${ }^{*}$ Corresponding author. E-mail: charleszedman@yahoo.com 
period, from months to even years, and function as a compound solution for erosion control (Davies 2000). The use of geotextiles prevents superficial runoff on steep slopes and thus decreases erosion rates by $\sim 50 \%$ (Rickson 2006; Alvarez-Mozos et al. 2014). The application of geotextiles also affects soil moisture conditions (Guerra et al. 2014).

The application of materials as geofibres, geo-membranes, geotextiles or biogeotextiles are sufficiently understood and documented (e.g. Jankauskas et al. 2012; Paterson et al. 2011; Guerra et al. 2015; Bhattacharyya et al. 2011c). The primary function of placing biogeotextile mats on bare soil is to decrease the amount and velocity of runoff, thereby decreasing sediment loss. If the amounts of runoff and sediment loss are decreased, the potential for re-vegetation of the soil surface is increased. Details of the manufacturing processes of biogeotextiles (i.e. jute-mats, coir and palm-leaf mats) and their salient properties are documented in several publications (e.g. Paterson et al. 2011; Bhattacharyya et al. 2011c).

The classification of geotextiles used in soil erosion control depends on the type of materials, as they can be natural or synthetic. Synthetic geotextiles are created from polymeric synthetic materials (e.g. nylon, polyethylene, polyester and polypropylene). Their material composition and treatment processes determine their durability and endurance in field conditions (Bhattacharyya et al. 2010b; Saha et al. 2012, 2014, 2015). Geotextiles constructed from natural fibres can last up to five years in field environments, depending on the prevailing weather conditions, while synthetic geotextiles can last over 25 years (Bhattacharyya et al. 2010a; Tapobrata 2017). Natural geotextiles provide a stable, non-eroding environment, and when constructed using indigenous materials, they can be very effective, affordable and compatible with sustainable land management practices (Bhattacharyya et al. 2011b; Jorge et al. 2016). Biological geotextiles (biogeotextiles) are potentially excellent biodegradable and environmentallyfriendly materials useful for soil conservation (Methacanon et al. 2010; Fullen et al. 2011b; Bhattacharyya et al. 2011a). On the other hand, synthetic geotextiles are non-biodegradable and their extensive use can cause soil contamination, therefore causing ecological and economic problems (Methacanon et al. 2010; Guerra et al. 2015; Bhattacharyya et al. 2011c). Biogeotextiles are produced from organic materials, usually plant fibres, such as coir, cereal straw, jute and palm-leaves.

Biogeotextiles have been utilized in multiple conditions world-wide to restore degraded soils and have yielded positive results (Bhattacharyya et al. 2010b; Methacanon et al. 2010; Jankauskas et al. 2012; Fullen et al. 2011b; Guerra et al. 2015). Of course, the geochemical composition of biogeotextiles is closely related to the constituents of the plant fibres used in their production (Smets et al. 2011; Chen et al. 2011; Jakab et al. 2012). For instance, geotextiles made from plants that contain plant nutrients can promote more rapid vegetation growth. Therefore, it is advisable to evaluate the geochemical composition of plant fibres used as biogeotextiles (Bhattacharyya et al. 2010b, 2011; Methacanon et al. 2010; Jankauskas et al. 2012; Fullen et al. 2011b; Guerra et al. 2015). It is therefore proposed that geochemical analysis should be an essential process in the selection of plant fibres for potential use in the production of geotextiles. Despite effective and successful application of plant fibres as geotextiles for the reclamation of environmentally-degraded lands, field and laboratory studies on possible geochemical effects of biogeotextiles (including heavy metal contamination) on soils are limited.

In this study, geochemical analysis of coir, jute, banana and palm-leaf fibres was conducted to determine their geochemical properties and infer the likely effects of their decomposition on soil systems. The aim is to analyse the geochemical content of selected geotextile fibres and to determine the elements that could potentially be nutrients for plants or cause heavy metal contamination in soils.

\section{Materials and methods}

Geochemical analyses were conducted on selected plant fibres which are used for making biogeotextiles worldwide and some potential biogeotextile plant fibres. The study examined two parts of the banana plant, namely banana-leaf and banana-leaf/stem, together with two different forms of jute plant (in both cloth and mat form). The other analysed materials included buriti palm-leaf and coir fibre. Several samples of plantain leaves/stem from different countries were analysed (Table 1). These include three banana-leaf/stem samples from Macaé, Rio de Janeiro (RJ) State, Brazil; three banana leaf samples from São Romão, RJ State, Brazil, three banana-leaf samples from Ubatuba, São Paulo (SP) State, Brazil and six samples of banana- leaf/stem from Oleo, RJ State, Brazil. In addition, banana- leaves from Lagos, Nigeria, were also analysed. In all four plant species were analysed, namely: buriti palm (Mauritia flexuosa) leaf from São Luís, Maranhão State, Brazil; banana (Musa spp.) leaf samples from Ubatuba, SP State, and São Romão and Oleo (RJ) and Nigeria (Lagos); jute fibre (Corchorus spp.) from India and coir coconut fibre (Cocos nucifera) from Brazil.

\subsection{Sample preparation}

Several samples of banana-leaves/stem were analysed. Ashes of the leaves/stems (semi-burnt) were acquired from several cities in Brazil, including São Pedro (RJ), Ubatuba (SP) and from the Campus of the Federal University of Rio de Janeiro (UFRJ), Brazil. Some fresh banana-leaves were also acquired from Lagos, Nigeria. The weights of the air-dried and oven-dried (at $40^{\circ} \mathrm{C}$ ) banana-leaves from Nigeria were taken. The aim of the geochemical analyses of the banana-leaves from two different continents was to determine the comparability and consistency of plant nutrient contents. Analyzing multiple sample types from a single location was to investigate possible influences of soil and environmental conditions on plant nutrient content. 
Similarly, air-dried buriti palm (Mauritia flexuosa) was utilized for this analysis. The buriti geotextile mat was acquired from previous buriti projects during which geotextile mats were constructed from buriti-leaves (Adeitun 2011). Coir fibre was also sourced from a previous experimental project (Fullen et al. 2011a, 2011b). Jute fibres used for this analysis were in two different fabricated material forms (mat and cloth) acquired from India.

Sample weights were obtained individually at each stage of sample preparation for X-ray diffraction (XRD) and X-ray fluorescence (XRF) spectrometry. All materials were individually pulverised in preparation for X-ray diffraction (XRD) analysis, while the overall weights of the ashes were also measured in preparation for XRF analysis.

\subsection{Preparation of samples for $\mathrm{X}$-ray diffraction (XRD) analysis}

$\mathrm{X}$-ray diffraction (XRD) analysis was performed on samples to identify their geochemical composition. In XRD analysis, X-rays of known wavelength are passed through the samples to be analysed, in order to identify the crystal structure of the samples. Due to their wave nature, X-rays are diffracted by the lattice of the sample crystal to give distinctive peak patterns of reflections at different angles and intensities. The X-ray detector then measures the position and intensity of the peak patterns. These peak patterns and other components assist the database search to detect and classify the chemical compounds in each sample (Stanjek, Hausler 2004). The X-ray analyser used has a copper anode with an electrical output of 3,000 watts.

All analysed samples were weighed. The leaf samples that had little moisture content were air-dried for one week, and then later oven-dried for 16 hours (overnight) at $40{ }^{\circ} \mathrm{C}$. For the XRD machine to analyse the samples accurately, the samples must be in powder form. Samples were individually ground to powder consistency using a Timor grinding mill, and then stored in individual labelled sample bags. The iron mill mortar ring grinder/crusher, iron piston crusher and mortar cover were thoroughly cleaned using sample paper and ethanol after grinding each sample, to prevent cross-contamination of samples. All powdered samples were later weighed.

\subsection{Preparation of samples for $\mathrm{X}$-ray fluorescence (XRF) analysis}

An X-ray fluorescence (XRF) analyser was used to determine the elemental constituents of samples. Oven-dried ash samples were placed into sample pots sealed with Mylar film at the base. This was performed to guarantee that the geometry of the tube-sample-detector assembly remained constant (Thomsen, Schatzlein 2002). The pots were then positioned in the XRF machine, which classifies elements in the samples by beaming X-rays onto them. The elements in the samples were later bombarded and excited by the X-rays, with each element in the sample emitting a specific $\mathrm{X}$-ray signature. All emitted individual
Table 1. Sample locations and description of the study area

\begin{tabular}{|c|c|c|}
\hline $\begin{array}{l}\text { Sample } \\
\text { No }\end{array}$ & $\begin{array}{c}\text { Sample } \\
\text { codes }\end{array}$ & Sample type/source \\
\hline 1 & BLL & Banana-leaf (Lagos, Nigeria) \\
\hline 2 & BUPLSB & $\begin{array}{l}\text { Buriti palm-leaf (São Luís, Maranhão } \\
\text { State, north-east Brazil) }\end{array}$ \\
\hline 3 & COFB & Coir fibre (Brazil) \\
\hline 4 & JUCI & Jute-cloth (India) \\
\hline 5 & JUMI & Jute-mat (India) \\
\hline 6 & BLSMA1 & $\begin{array}{l}\text { Banana-leaf/stem } 1 \text { (Macaé, } \\
\text { Rio de Janeiro State, Brazil) }\end{array}$ \\
\hline 7 & BLSMA2 & $\begin{array}{l}\text { Banana-leaf/stem } 2 \text { (Macaé, } \\
\text { Rio de Janeiro State, Brazil) }\end{array}$ \\
\hline 8 & BLSMA3 & $\begin{array}{l}\text { Banana-leaf/stem } 3 \text { (Macaé, } \\
\text { Rio de Janeiro State, Brazil) }\end{array}$ \\
\hline 9 & BLSA1 & $\begin{array}{l}\text { Banana-leaf } 1 \text { (São Romão, } \\
\text { Rio de Janeiro State, Brazil) }\end{array}$ \\
\hline 10 & BLSA2 & $\begin{array}{l}\text { Banana-leaf } 2 \text { (São Romão, } \\
\text { Rio de Janeiro State, Brazil) }\end{array}$ \\
\hline 11 & BLSA3 & $\begin{array}{l}\text { Banana-leaf } 3 \text { (São Romão, } \\
\text { Rio de Janeiro State, Brazil) }\end{array}$ \\
\hline 12 & BLUT1 & $\begin{array}{l}\text { Banana-leaf } 1 \text { (Ubatuba, São Paulo } \\
\text { State, Brazil) }\end{array}$ \\
\hline 13 & BLUT2 & $\begin{array}{l}\text { Banana-leaf 2 (Ubatuba, São Paulo } \\
\text { State, Brazil) }\end{array}$ \\
\hline 14 & BLUT3 & $\begin{array}{l}\text { Banana-leaf } 3 \text { (Ubatuba, São Paulo } \\
\text { State, Brazil) }\end{array}$ \\
\hline 15 & BLSOL1 & $\begin{array}{l}\text { Banana-leaf/stem } 1 \text { (Oleo, } \\
\text { Rio de Janeiro State, Brazil) }\end{array}$ \\
\hline 16 & BLSOL2 & $\begin{array}{l}\text { Banana-leaf/stem } 2 \text { (Oleo, } \\
\text { Rio de Janeiro State, Brazil) }\end{array}$ \\
\hline 17 & BLSOL3 & $\begin{array}{l}\text { Banana-leaf/stem } 3 \text { (Oleo, } \\
\text { Rio de Janeiro State, Brazil) }\end{array}$ \\
\hline 18 & BLSOL4 & $\begin{array}{l}\text { Banana--leaf/stem } 4 \text { (Oleo, } \\
\text { Rio de Janeiro State, Brazil) }\end{array}$ \\
\hline 19 & BLSOL5 & $\begin{array}{l}\text { Banana-leaf/stem } 5 \text { (Oleo, } \\
\text { Rio de Janeiro State, Brazil) }\end{array}$ \\
\hline 20 & BLSOL6 & $\begin{array}{l}\text { Banana- leaf/stem } 6 \text { (Oleo, } \\
\text { Rio de Janeiro State, Brazil) }\end{array}$ \\
\hline
\end{tabular}

$\mathrm{X}$-ray signatures are therefore equivalent to the energy profiles of one of the elements in the ash sample (Kaniu et al. 2012).

The semi-burnt banana-leaf ashes from Brazil and the leaf/fibre powder samples derived after XRD analysis were all used for XRF analysis. Individual samples were all placed in crucibles and weighed. Samples were later placed inside an oven $\left(\right.$ at $40^{\circ} \mathrm{C}$ ) for 30 minutes and then placed in glass desiccators with silica gel below to absorb any remaining moisture. They were weighed to ascertain the weight loss from moisture content and the oven-dry weight of samples. Then, samples in the crucibles were placed in a muffle furnace at $500{ }^{\circ} \mathrm{C}$ for 3 hours. The samples were ignited and left in ash form; this action ignited the organic fraction, thereby leaving only the minerals in 
the ash samples. After this, samples were left to cool in the furnace. The weight of the ash obtained from each sample was recorded and the percentage ash was calculated in order to determine the amount of organic matter loss in each sample due to burning. The quantity of ash samples derived was sufficient to cover the bottom of the pot, which was earlier covered with Mylar film, which was necessary for XRF analysis. Ash samples were then added to pots and analysed for elemental constituents using an XRF spectrometer (Spectro/Model: Xepos). Initial sample weights ranged between $0.09-10.0 \mathrm{~g}$ of pulverized plant fibre, while the ash weights left after burning were between 0.01-1.68 g. Thus, the organic matter content of the plant fibres constituted $87-99 \%$ of the oven-dried samples.

\subsection{Methods of statistical analysis}

Several descriptive statistical analyses were conducted, using the IBM SPSS Statistical Package (2015 versions). This software helped to analyse correlations, trends and the statistical significance of differences within the geochemical data. The applied statistical techniques included Factor Analysis using Principal Component Analysis (PCA), Analysis of Variance (ANOVA) and descriptive statistical analyses. The PCA analysis is a linear combination of optimally-weighted observed variables used to establish principal components (i.e. smaller numbers of artificial variables) that could possibly account for the variance within the geochemical data. Similarly, ANOVA was applied to the geochemical data to establish whether the observed variance or differences between various samples are statistically significant.

\section{Results and discussion}

XRD analyses were first conducted on the five ash samples. The peak patterns were investigated in the XRD database in order to determine the component compounds of the individual samples. The probable potential minerals in organic plant tissues according to the XRD database were: arcanite $\left(\mathrm{K}_{2} \mathrm{SO}_{4}\right)$, calcium borate hydrate $\left(\mathrm{Ca}_{3}\left(\mathrm{BO}_{3}\right)_{2} \cdot \mathrm{H}_{2} \mathrm{O}\right)$, calcium silicide $\left(\underline{\mathrm{CaSi}}_{2}\right)$, cristobalite $\left(\mathrm{SiO}_{2}\right)$, celestine $\left(\underline{\mathrm{SrSO}}_{4}\right)$, calcium phosphate $\left(\mathrm{CaHPO}_{4}\right)$, hydrogrossular $\left(\mathrm{Ca}_{3} \mathrm{Al}_{2}\left(\mathrm{SiO}_{4}\right)_{3-\mathrm{x}}(\mathrm{OH})_{4 \mathrm{x}}\right)$, manganite $(\mathrm{MnO}(\mathrm{OH}))$, potassium nitrate $\left(\mathrm{KNO}_{3}\right)$, potassium oxalate hydrate $\left(\mathrm{K}_{2} \mathrm{C}_{2} \mathrm{O}_{4}\right.$. $\left.\mathrm{H}_{2} \mathrm{O}\right)$, potassium hydrate phosphate $\left(\mathrm{K}_{2} \mathrm{HPO}_{4}\right)$, rankinite $\left(\mathrm{Ca}_{3} \mathrm{Si}_{2} \mathrm{O}_{7}\right)$ and sodium formate (HCOONa) (Stanjek and Hausler 2004). However, the XRD scans of the samples and their individual peak patterns did not match any of the compounds listed above. This indicates that minerals present were less than the detectable limit, as most minerals are expected to be in very low concentrations in organic fibres (Kaniu et al. 2012).

\subsection{Macro-nutrient analysis}

Macronutrient concentrations of the samples are presented in Table 2 and Figure 1. Macro-nutrient concentrations
(Table 1) showed that potassium $(\mathrm{K})$ has the highest concentration (50.73\%) in banana-leaf from São Romão, while molybdenum (Mo) has the lowest concentration $(<0.0010 \%)$. K concentrations varied from $\sim 3.63 \%$ in jute-mat (from India) to $50.73 \%$ in banana-leaf (from São Romão) with a mean concentration of $27.12 \%$. Similarly, Calcium (Ca) concentrations varied from $0.09 \%$ in banana-leaf (from São Romão) to $37 \%$ in banana- leaf/ stem (from Oleo), with a mean of $10.49 \%$. The results, therefore, showed that $\mathrm{K}$ constituted a substantial proportion of the dry weight in each sample. The proportion of $\mathrm{Ca}$ in the samples was fairly high $(37 \%)$ in one of the banana leaf/stem samples from Oleo, while it was low $(0.90 \%)$ in the banana-leaf sample from São Romão. In addition, analysis of the two jute sample types showed that $\mathrm{Ca}$ concentration in the mat was higher (18.27\%) than in the cloth (11.93\%).

Table 2. Concentrations of macro-nutrients (\% by weight) in ash samples of plant tissues

\begin{tabular}{|c|c|c|c|c|c|c|}
\hline 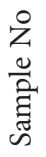 & $\begin{array}{l}\text { Sample } \\
\text { code }\end{array}$ & $\begin{array}{l}\text { Magne- } \\
\text { sium } \\
(\mathrm{Mg}) \%\end{array}$ & $\begin{array}{l}\text { Phos- } \\
\text { phorus } \\
\text { (P) \% }\end{array}$ & $\begin{array}{l}\text { Potas- } \\
\text { sium } \\
(\mathrm{K}) \%\end{array}$ & $\begin{array}{l}\text { Cal- } \\
\text { cium } \\
(\mathrm{Ca}) \%\end{array}$ & $\begin{array}{l}\text { Sul- } \\
\text { phur } \\
\text { (S) \% }\end{array}$ \\
\hline 1 & BLL & 8.94 & 3.18 & 39.84 & 3.21 & 3.70 \\
\hline 2 & BUPLSB & 12.05 & 9.54 & 14.67 & 8.26 & 1.43 \\
\hline 3 & COFB & 9.79 & 0.87 & 13.09 & 1.14 & 0.96 \\
\hline 4 & JUCI & 18.40 & 1.37 & 3.97 & 11.93 & 2.77 \\
\hline 5 & JUMI & 18.64 & 1.59 & 3.63 & 18.27 & 1.99 \\
\hline 6 & BLSMA1 & 17.48 & 1.29 & 30.53 & 2.34 & 2.50 \\
\hline 7 & BLSMA2 & 11.93 & 0.87 & 38.97 & 9.43 & 2.17 \\
\hline 8 & BLSMA3 & 16.02 & 2.54 & 31.52 & 5.83 & 3.90 \\
\hline 9 & BLSA1 & 9.82 & 4.51 & 50.73 & 0.90 & 4.10 \\
\hline 10 & BLSA2 & 13.24 & 1.08 & 31.62 & 9.85 & 3.56 \\
\hline 11 & BLSA3 & 13.95 & 3.11 & 36.92 & 0.94 & 4.44 \\
\hline 12 & BLUT1 & 12.12 & 4.98 & 34.84 & 6.55 & 3.81 \\
\hline 13 & BLUT2 & 19.75 & 5.88 & 29.77 & 8.12 & 2.81 \\
\hline 14 & BLUT3 & 12.07 & 4.73 & 39.44 & 5.05 & 1.58 \\
\hline 15 & BLSOL1 & 12.15 & 0.44 & 23.13 & 37.00 & 1.23 \\
\hline 16 & BLSOL2 & 22.55 & 1.89 & 15.28 & 19.94 & 1.43 \\
\hline 17 & BLSOL3 & 20.22 & 1.29 & 18.18 & 20.59 & 1.06 \\
\hline 18 & BLSOL4 & 15.41 & 2.43 & 25.42 & 10.01 & 1.60 \\
\hline 19 & BLSOL5 & 9.08 & 0.56 & 34.69 & 11.32 & 0.61 \\
\hline 20 & BLSOL6 & 19.76 & 0.98 & 26.94 & 19.15 & 1.29 \\
\hline
\end{tabular}

\subsection{Micro-nutrient analysis}

The concentrations of most micro-nutrients were low and below the calibration limits in most samples (Table 3, Figure 2). However, iron (Fe) concentrations varied from $0.15 \%$ in banana-leaf/stem samples (Oleo) to $4.47 \%$ in jute-cloth (India), with a mean concentration of $0.82 \%$. 
Similarly, manganese $(\mathrm{Mn})$ percentage concentration varied from $0.03 \%$ in banana-leaf/stem (Oleo) to $1.89 \%$ in banana-leaf/stem (Macaé), with a mean of $0.35 \%$. The percentages of copper $(\mathrm{Cu})$, zinc $(\mathrm{Zn})$, molybdenum (Mo) and cobalt (Co) were all below detectable limits in all ignited samples. Comparing the banana samples in the entire data-set, it can be observed that $\mathrm{Fe}$ in banana samples maintained a stable higher concentration than other elements. This provides strong evidence that banana-leaves have relatively high Fe contents (Table 1).

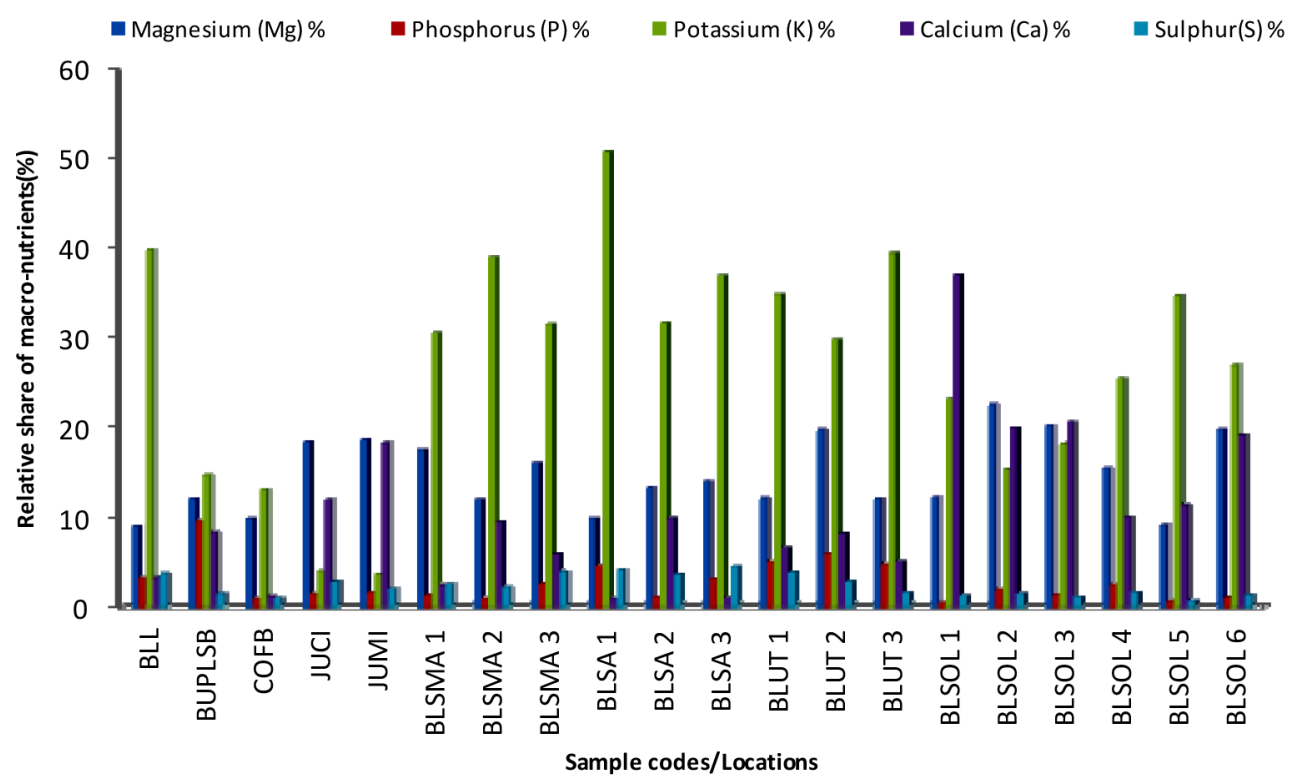

Figure 1. Concentrations of macro-nutrients (\% by weight) in ash samples of plant tissues

Table 3. Concentrations of micro-nutrients (\% by weight) in ash samples of plant tissues

\begin{tabular}{|c|c|c|c|c|c|c|c|c|}
\hline $\begin{array}{l}\text { Sample } \\
\text { No }\end{array}$ & $\begin{array}{l}\text { Sample } \\
\text { code }\end{array}$ & $\begin{array}{l}\text { Manganese } \\
\text { (Mn) \% }\end{array}$ & $\begin{array}{l}\text { Iron } \\
(\mathrm{Fe}) \%\end{array}$ & $\begin{array}{l}\text { Copper } \\
\text { (Cu) \% }\end{array}$ & $\begin{array}{l}\text { Zinc } \\
(\mathrm{Zn}) \%\end{array}$ & $\begin{array}{l}\text { Molybdenum } \\
\text { (Mo) \% }\end{array}$ & $\begin{array}{l}\text { Chlorine } \\
\text { (Cl) \% }\end{array}$ & $\begin{array}{l}\text { Cobalt } \\
\text { (Co) \% }\end{array}$ \\
\hline 1 & BLL & 0.17 & 0.40 & $<0.0087$ & $<0.0230$ & $<0.0010$ & 3.01 & $<0.0085$ \\
\hline 2 & BUPLSB & 0.15 & 0.55 & $<0.0111$ & $<0.0496$ & $<0.0029$ & 0.54 & $<0.0197$ \\
\hline 3 & COFB & 0.06 & 1.11 & $<0.0075$ & $<0.0250$ & $<0.0018$ & 8.18 & $<0.3208$ \\
\hline 4 & JUCI & 0.78 & 4.47 & $<0.0262$ & $<0.1606$ & $<0.0040$ & 0.16 & $<0.1473$ \\
\hline 5 & JUMI & 0.35 & 4.01 & $<0.0222$ & $<0.0514$ & $<0.0010$ & 0.43 & $<0.1252$ \\
\hline 6 & BLSMA1 & 0.31 & 0.19 & $<0.0016$ & $<0.0044$ & $<0.0010$ & 5.13 & $<0.0018$ \\
\hline 7 & BLSMA2 & 1.89 & 0.26 & $<0.0042$ & $<0.0126$ & $<0.0054$ & 9.23 & $<0.0017$ \\
\hline 8 & BLSMA3 & 1.43 & 0.53 & $<0.0065$ & $<0.0178$ & $<0.0010$ & 4.11 & $<0.0025$ \\
\hline 9 & BLSA1 & 0.14 & 0.26 & $<0.0179$ & $<0.0296$ & $<0.0010$ & 2.67 & $<0.0016$ \\
\hline 10 & BLSA2 & 0.44 & 0.65 & $<0.0211$ & $<0.0431$ & $<0.0010$ & 9.91 & $<0.0025$ \\
\hline 11 & BLSA3 & 0.07 & 0.41 & $<0.0014$ & $<0.0062$ & $<0.0024$ & 3.72 & $<0.0023$ \\
\hline 12 & BLUT1 & 0.23 & 0.24 & $<0.0087$ & $<0.0193$ & $<0.0010$ & 8.37 & $<0.0018$ \\
\hline 13 & BLUT2 & 0.26 & 0.17 & 0.0122 & 0.0177 & 0.0010 & 6.56 & 0.0003 \\
\hline 14 & BLUT3 & 0.14 & 0.30 & $<0.0098$ & $<0.0104$ & $<0.0044$ & 12.58 & $<0.0018$ \\
\hline 15 & BLSOL1 & 0.11 & 0.43 & $<0.0041$ & $<0.0138$ & $<0.0010$ & 2.32 & $<0.0022$ \\
\hline 16 & BLSOL2 & 0.15 & 0.29 & $<0.0046$ & $<0.0142$ & $<0.0010$ & 2.85 & $<0.0019$ \\
\hline 17 & BLSOL3 & 0.07 & 0.44 & $<0.0045$ & $<0.0146$ & $<0.0073$ & 5.25 & $<0.0022$ \\
\hline 18 & BLSOL4 & 0.10 & 0.65 & $<0.0050$ & $<0.0157$ & $<0.0056$ & 5.68 & $<0.0026$ \\
\hline 19 & BLSOL5 & 0.03 & 0.15 & $<0.0033$ & $<0.0076$ & $<0.0010$ & 17.11 & $<0.0013$ \\
\hline 20 & BLSOL6 & 0.07 & 0.22 & $<0.0013$ & $<0.0085$ & $<0.0010$ & 3.44 & $<0.0017$ \\
\hline
\end{tabular}

Note: Numbers with the prefix ' $<$ ' means below the current XRF calibration range. Therefore, values should be interpreted as semiquantitative. 
Chlorine $(\mathrm{Cl})$ had the highest percentage of all the micro-nutrients, at $17.11 \%$ (in banana-leaf/stem from Oleo). Similarly, the results showed that $\mathrm{Cu}, \mathrm{Zn}, \mathrm{Mo}$ and Co concentrations were below calibration limits in all ignited samples. In banana-leaf and banana-leaf/stem samples, Mn was only $0.07 \%$, while its highest concentration was $1.89 \%$ in the banana-leaf/stem sample from Rio de Janeiro State (Figure 2). The highest micro-nutrient concentration was $\mathrm{Cl}$ in the Brazilian banana-leaf and banana-leaf/stem samples. The buriti palm and coir fibre samples had relatively low concentrations for all elements $(<1 \%)$, with most elemental concentrations below detectable limits. Generally, the Brazilian samples had higher concentrations of macro-nutrients than samples from other countries, especially $\mathrm{Cl}$ in banana-leaf and banana-leaf/stem samples.

Adeitun (2011) reported low concentrations $(<1 \%)$ of most micro-elements in analysed plant fibre samples and the concentrations of the micro-nutrients below detectable limits in most samples. Fe had the highest percentage of all the micro-elements, with a concentration of $0.69 \%$ (in banana-stem). Fe also has the highest concentration compared with other micro-elements in banana-leaf and banana-leaf/stem samples (Adeitun 2011). The three samples (banana-leaf, banana- leaf/stem and banana-stem) had fairly consistent $\mathrm{Mn}$ concentrations $(0.30,0.19$ and $0.18 \%$, respectively) (Adeitun 2011). The results accord with analysis of Jamaican palm-leaves showing very low concentrations of all micro-elements (Shepherd 2012). Assessing the overall micro-element results, Fe in the banana samples had higher concentrations than other elements in the experimental results of both Adeitun (2011) and Shepherd (2012).

\subsection{Heavy metal analysis}

Heavy metal concentrations are presented in Table 4 and Figure 3. Chromium (Cr) had the highest concentration
$(0.026 \%)$ in jute-cloth, while its concentration in banana samples were all $<1 \%$, ranging from $0.0138-<0.0025 \%$. Nickel (Ni), arsenic (As), selenium $(\mathrm{Se})$, lead $(\mathrm{Pb})$ and mercury $(\mathrm{Hg}$ ) all had very low concentrations (ranging from $0.0236-<0.00010 \%$ ). Comparison of each element across the samples showed that Se and $\mathrm{Hg}$ were below the calibration limits in all samples. For other samples, such as the buriti palm sample, Cr was $0.0076 \%$, with the coir fibre and banana samples recording even lower concentrations. Although most samples revealed the presence of heavy metals, such as $\mathrm{As}$ and $\mathrm{Pb}$, their concentrations were below detectable limits. Ni concentrations were relatively low in all samples; the highest was $0.016 \%$ and the lowest $0.005 \%$. Therefore, the low heavy metal concentrations present strong evidence that heavy metal toxicity does not pose a potential source of soil contamination on decomposition of these biogeotextile fibres. Heavy metals in plants obstruct nutrient uptake and impede plant growth (Jadia, Fulekar 2009; Guerra et al. 2015), which would limit the suitability of such fibres for use as biogeotextiles. Furthermore, heavy metals can be highly toxic to soil fauna and flora and further decrease soil fertility, which in turn may increase soil erodibility (Guerra et al. 2015).

\subsection{Total nutrient concentration analysis}

The proportion of macro-nutrients in the samples constituted $26-74 \%$ of the total concentrations of elements in each sample. The banana-stem and banana-leaf samples had higher proportions of all macro-nutrients, compared with the other samples, while the proportions of the remaining samples were $<50 \%$ (Table 5, Figure 4). However, considering the entire elements together, $\mathrm{K}$ had the highest concentration of $50.73 \%$ (for banana-leaf from São Romão), while Mo had the least at $<0.0010 \%$ (banana-leaf from Lagos, jute-mat from India, banana- leaf/ stem from Rio de Janeiro, banana-leaf from São Romão,

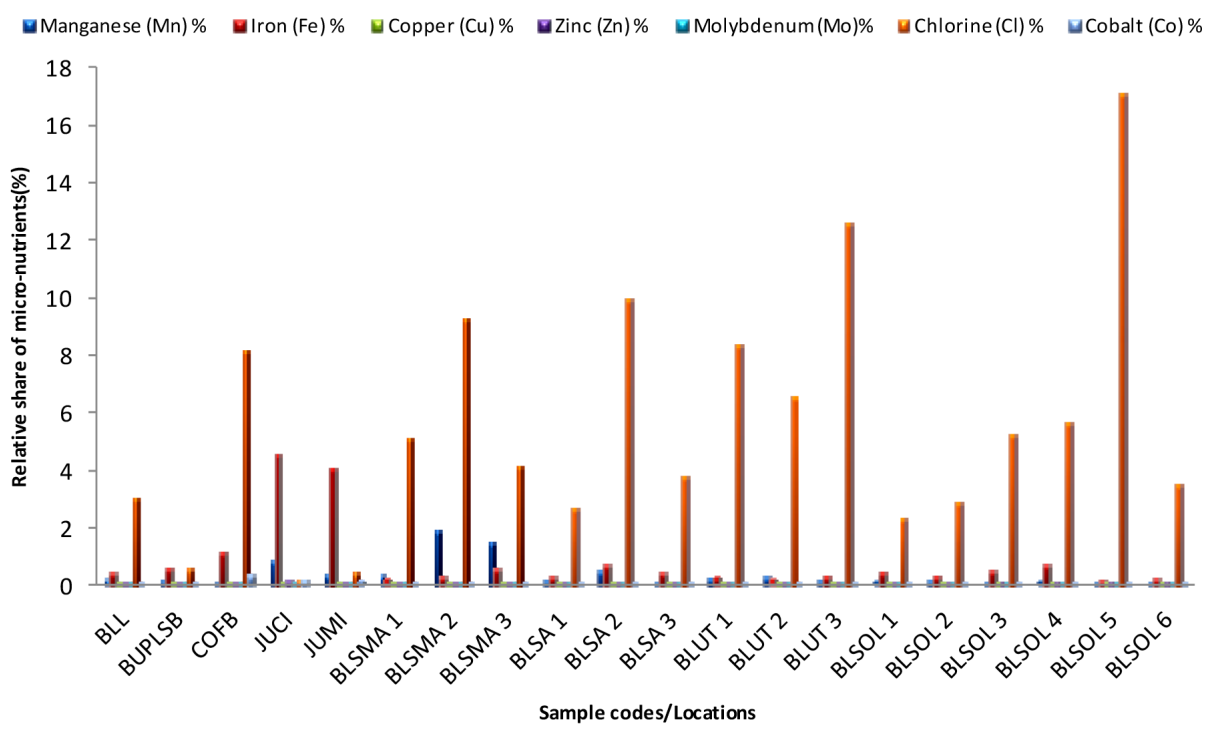

Figure 2. Concentrations of micro-nutrients (\% by weight) in ash samples of plant tissues 
banana-leaf from Ubatuba, and banana- leaf/stem from Oleo). Comparing the percentage concentrations of each of the macro-elements across the samples showed that $\mathrm{K}$ was highest in banana-leaf from São Romão, while P has the lowest concentration of $0.44 \%$ in banana-leaf/stem from Oleo. Coir fibre samples from Brazil had high $\mathrm{K}$ concentrations (13.09\%) and the least concentration of Mo $(<0.0018$, below detectable limits). Comparing the

Table 4. Concentrations of heavy metals (\% by weight) in ash samples of plant tissues

\begin{tabular}{|c|c|c|c|c|c|c|c|}
\hline $\begin{array}{c}\text { Sample } \\
\text { No }\end{array}$ & $\begin{array}{c}\text { Sample } \\
\text { codes }\end{array}$ & $\begin{array}{l}\text { Arsenic, } \\
\text { As (\%) }\end{array}$ & $\begin{array}{c}\text { Chromium, } \\
\text { Cr (\%) }\end{array}$ & $\begin{array}{l}\text { Lead, } \\
\mathrm{Pb}(\%)\end{array}$ & $\begin{array}{c}\text { Mercury, } \\
\text { Hg (\%) }\end{array}$ & $\begin{array}{l}\text { Nickel, } \\
\text { Ni (\%) }\end{array}$ & $\begin{array}{l}\text { Selenium, } \\
\text { Se (\%) }\end{array}$ \\
\hline 1 & BLL & $<0.00034$ & 0.0061 & 0.0020 & $<0.00083$ & 0.0068 & $<0.00027$ \\
\hline 2 & BUPLSB & 0.0005 & 0.0076 & 0.0008 & $<0.0023$ & 0.0069 & $<0.00057$ \\
\hline 3 & COFB & 0.0005 & 0.0060 & 0.0011 & $<0.0051$ & 0.0061 & $<0.0014$ \\
\hline 4 & JUCI & 0.0039 & 0.0264 & 0.0236 & $<0.0046$ & 0.0160 & $<0.0012$ \\
\hline 5 & JUMI & 0.0011 & 0.0097 & 0.0041 & $<0.0037$ & 0.0102 & $<0.0010$ \\
\hline 6 & BLSMA1 & $<0.00010$ & 0.0026 & $<0.00034$ & $<0.00016$ & 0.0062 & $<0.00016$ \\
\hline 7 & BLSMA2 & $<0.00031$ & 0.0138 & 0.0008 & $<0.00044$ & 0.0089 & $<0.00020$ \\
\hline 8 & BLSMA3 & $<0.00027$ & $<0.0025$ & 0.0006 & $<0.00042$ & 0.0077 & $<0.00016$ \\
\hline 9 & BLSA1 & $<0.00029$ & 0.0069 & 0.0008 & $<0.00042$ & 0.0076 & $<0.00021$ \\
\hline 10 & BLSA2 & 0.0003 & 0.0058 & 0.0007 & $<0.00022$ & 0.0111 & 0.00019 \\
\hline 11 & BLSA3 & $<0.00021$ & 0.0050 & 0.0003 & $<0.00025$ & 0.0052 & $<0.00015$ \\
\hline 12 & BLUT1 & $<0.00026$ & $<0.0030$ & 0.0008 & $<0.00027$ & 0.0067 & $<0.00020$ \\
\hline 13 & BLUT2 & 0.0007 & $<0.00050$ & $<0.00020$ & $<0.00020$ & 0.0087 & $<0.00010$ \\
\hline 14 & BLUT3 & $<0.00024$ & 0.0033 & 0.0009 & $<0.00033$ & 0.0072 & $<0.00019$ \\
\hline 15 & BLSOL1 & $<0.00028$ & 0.0075 & $<0.00056$ & $<0.00045$ & 0.0057 & $<0.00022$ \\
\hline 16 & BLSOL2 & $<0.00025$ & $<0.0027$ & $<0.00048$ & $<0.00041$ & 0.0053 & $<0.00019$ \\
\hline 17 & BLSOL3 & $<0.00027$ & 0.0045 & 0.0008 & $<0.00043$ & 0.0051 & 0.00023 \\
\hline 18 & BLSOL4 & $<0.00027$ & 0.0040 & 0.0007 & $<0.00034$ & 0.0052 & 0.00016 \\
\hline 19 & BLSOL5 & 0.0003 & $<0.0026$ & $<0.00051$ & $<0.00036$ & 0.0050 & $<0.00022$ \\
\hline 20 & BLSOL6 & $<0.00023$ & 0.0064 & $<0.00034$ & $<0.00042$ & 0.0057 & $<0.00019$ \\
\hline
\end{tabular}

Note: Numbers with the prefix ' $<$ ' means below the current XRF calibration range. Therefore values should be interpreted as semiquantitative.

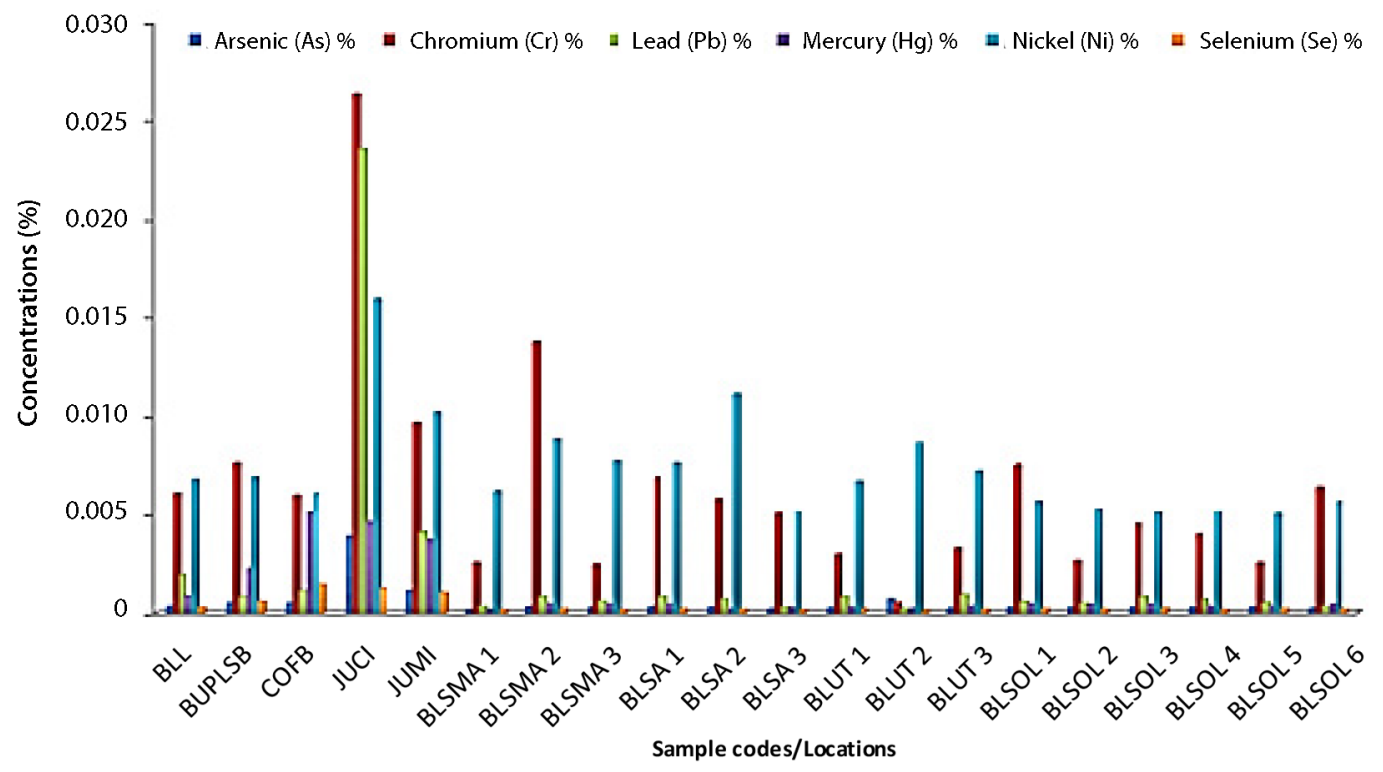

Figure 3. Concentrations of heavy metals (\% by weight) in ash samples from ignited plant tissues 
jute-cloth and mat, jute-mat had more $\mathrm{Mg}(18.64 \%)$ and the lowest element concentration was Mo $(<0.001 \%)$. The banana-leaf from Nigeria and the three regions in Brazil had relatively high K concentrations. Banana-leaf samples also had higher $\mathrm{K}$ concentrations than the coir fibre and the two jute forms.

When viewed across all samples, $\mathrm{P}$ concentration was highest $(9.54 \%)$ in buriti palm-leaf and least $(0.44 \%)$ in one of the three banana-leaf/stem samples from Oleo. Ca concentration was high (37.0\%) in one of the banana-leaf/ stem samples from Oleo, but was low $(0.90 \%)$ in one of the banana-leaf samples from São Romão. Between the two jute forms, Ca concentration was higher in the mat (18.27\%) than the cloth (11.93\%). Considering the different growing requirements of plants, the Ca content of plants should be $>5 \%$ dry weight (Marschner 1993). Therefore, the percentages of $\mathrm{Ca}$ in all samples are still within the optimum growth range, except for some banana-leaf and coir fibre samples. Similarly, K constituted a substantial proportion of the dry weight of all samples. Banana-leaf had the highest $\mathrm{K}$ content of the dry weight of the entire samples, while the least was banana-leaf/stem. Since at a peak growth, the $\mathrm{K}$ content of plant tissues should be $>5 \%$ dry weight (Bakker, Elbersen 2005), all samples therefore indicated optimal growth potential, as their $\mathrm{K}$ concentrations were $>5 \%$, except for the two jute samples. Adeitun (2011) showed that banana-leaf samples have high $\mathrm{Ca}$ contents and that $\mathrm{K}$ concentrations were greater in banana-leaf but low in banana-stem (Adeitun 2011). Similarly, most macro-nutrients (particularly Mg, P and K) were generally low in banana-stem (Adeitun 2011). Evaluating the entire macro-element data of this study showed that $\mathrm{K}$ in banana-leaves had higher concentrations than other elements, which therefore provides very strong evidence that banana-leaves generally have relatively high $\mathrm{K}$ concentrations.

High $\mathrm{K}$ and Ca concentrations in plant fibres accord with a study on banana-leaf samples from Jamaica (Shepherd 2012). Coir fibres (which had the lowest proportion of macro-nutrients in this study) have been previously used to construct effective biogeotextiles (Bhattacharyya et al. 2011; Fullen et al. 2011a; Kertész et al. 2011). Coir mats have been successfully applied in many gully rehabilitation projects world-wide, although coir is less likely to add nutrients to soil systems on decomposition (Fullen et al. 2011a; Chen et al. 2011; Guerra et al. 2015; Shirazi et al. 2016; Vasarevičius et al. 2016; Shokr et al. 2016; Jarašiūnas, Kinderienè 2016). Therefore, other types of plant fibre with higher proportions of macro-elements may make better biogeotextiles, with higher nutrient concentrations than coir fibre. Geotextiles constructed from plant fibres with higher nutrient concentrations supplement more nutrients into the soil system and thus promote more rapid vegetation growth and hence more effective soil conservation (Smets et al. 2011). High nutrient concentrations in soil also increase soil aggregate stability and thus decrease soil erodibility (Smets et al. 2011; Guerra et al. 2017). The four sample types (banana-leaf/stem, banana-leaf, buriti-palm and jute-mat) therefore have supplementary benefits of adding nutrients to soil systems, besides their primary role of conserving soils.

Synthetic geotextiles are still frequently used although they often become redundant once vegetation has been established on-site and therefore can lead to soil contamination and ecological problems (Fullen et al. 2011a, 2011b). The comparative merits of biogeotextiles and synthetic should be carefully considered before field applications. Generally, biogeotextiles are effective, affordable and compatible with sustainable land management practises (Bhattacharyya et al. 2011a, 2011b).

Field studies have established that the decomposition of biogeotextiles varies with environmental conditions, especially climate. Biogeotextiles can last from a few months to a few years. Rapid decomposition of biogeotextiles over about three months was observed in the humid tropics of Brazil. However, at the São Luis gully site, the biogeotextiles gave ample protection, allowing sufficient time for the establishment of a dense grass cover. In constrast, in the humid temperate climate of the British Isles (England and the Isle of Man) biogeotextiles remained viable for about two years before decomposition (Fullen et al. 2011b; Bhattacharyya et al. 2011a, 2011b).

Table 5. Combined concentrations of macro-nutrients (\% by weight) in ash samples from ignited plant tissues

\begin{tabular}{|c|c|c|}
\hline $\begin{array}{l}\text { Sample } \\
\text { No }\end{array}$ & $\begin{array}{l}\text { Sample } \\
\text { codes }\end{array}$ & $\begin{array}{l}\text { Total proportion of macro- } \\
\text { elements (\% by weight) }\end{array}$ \\
\hline 1 & BLL & 58.87 \\
\hline 2 & BUPLSB & 45.95 \\
\hline 3 & COFB & 25.86 \\
\hline 4 & JUCI & 38.44 \\
\hline 5 & JUMI & 44.12 \\
\hline 6 & BLSMA1 & 54.15 \\
\hline 7 & BLSMA2 & 63.36 \\
\hline 8 & BLSMA3 & 59.81 \\
\hline 9 & BLSA1 & 70.06 \\
\hline 10 & BLSA2 & 59.34 \\
\hline 11 & BLSA3 & 59.35 \\
\hline 12 & BLUT1 & 62.30 \\
\hline 13 & BLUT2 & 66.33 \\
\hline 14 & BLUT3 & 62.86 \\
\hline 15 & BLSOL1 & 73.96 \\
\hline 16 & BLSOL2 & 61.08 \\
\hline 17 & BLSOL3 & 61.33 \\
\hline 18 & BLSOL4 & 54.87 \\
\hline 19 & BLSOL5 & 56.25 \\
\hline 20 & BLSOL6 & 68.12 \\
\hline
\end{tabular}

\subsection{Statistical analysis of geochemical data}

Factor Analysis of the geochemical data was conducted using Principal Component Analysis (PCA), with varimax rotation to assess the clustering of the nutrient data. 


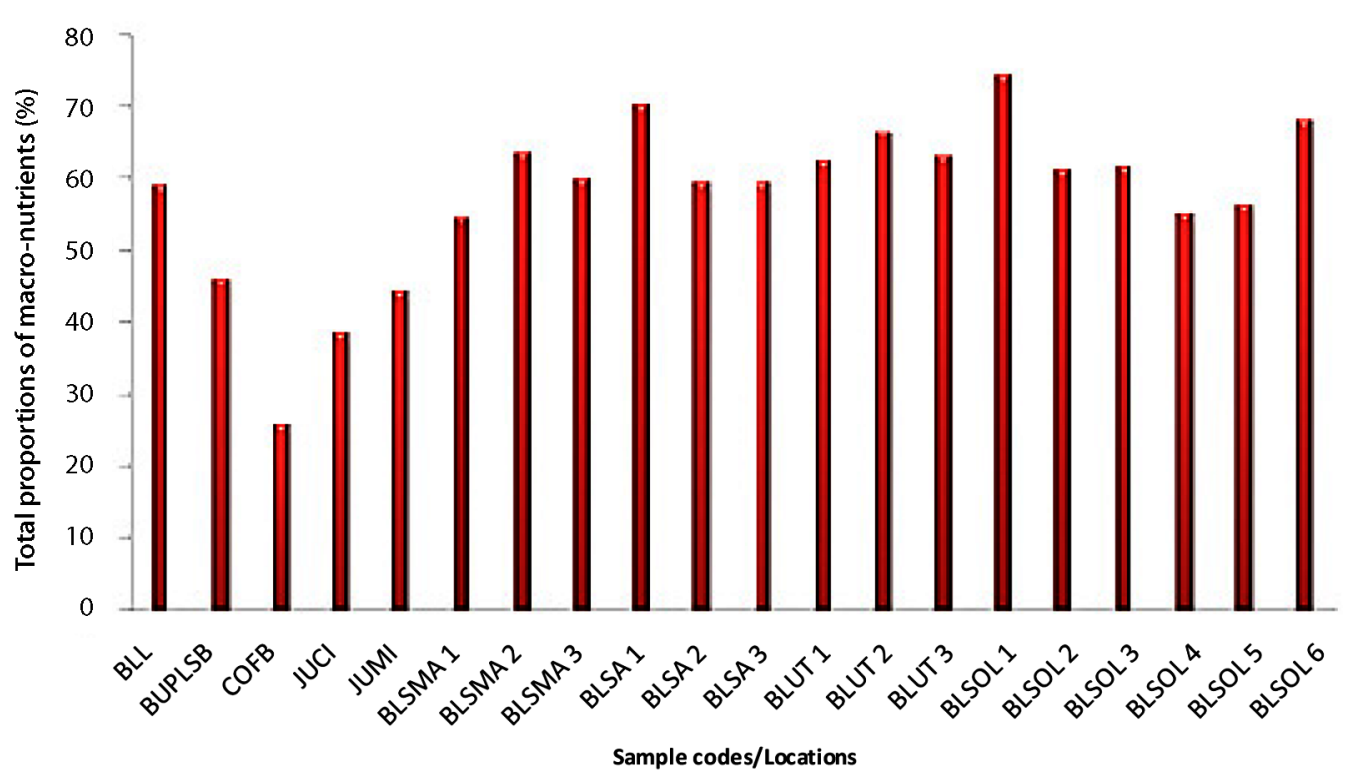

Figure 4. Combined concentrations of macro-nutrients (\% by weight) in ignited plant tissues

The variables were $\mathrm{Mg}, \mathrm{P}, \mathrm{K}, \mathrm{Ca}$ and $\mathrm{S}$. The total variance explained for the micro-nutrients is reported in Table 6, which showed only one component with an initial Eigenvalue $>1.0$. After rotation, this principal component accounted for $49.713 \%$ of variance. The rotated component matrix showed the loadings of the rotated components, with loadings $<0.30$ omitted to improve clarity (Table $6 \mathrm{~b}$ ). Results suggest that, in accordance with zero-order correlations, this component increases with increasing $\mathrm{K}, \mathrm{S}$ and $\mathrm{P}$ concentrations, with correlation $(\mathrm{r})$ coefficients of $0.765,0.729$ and 0.440 , respectively. The principal component has negative correlations with $\mathrm{Ca}$ and $\mathrm{Mg}$, ( $\mathrm{r}=$ -0.800 and -0.733 , respectively). Results imply generally positive correlations between nutrient concentrations.

PCA with varimax rotation was also conducted on the micro-nutrient data (i.e. $\mathrm{Mn}, \mathrm{Fe}, \mathrm{Cu}, \mathrm{Zn}, \mathrm{Mo}, \mathrm{Cl}$ and $\mathrm{Co}$ ). Three components have initial Eigenvalues $>1.0$ (Table 7). The first principal component (PC1) accounted for $36.84 \%$ of variance. PC2 accounted for $23.026 \%$ of variance, while PC3 accounted for $16.24 \%$. Fe, Cu, $\mathrm{Zn}, \mathrm{Cl}$ and Co have high positive loadings, with correlation coefficients of $\mathrm{r}=$ $0.951,0.576,0.845,-0.602$ and 0.609 , respectively.

Mo has a high loading in the second principal component $(r=0.842)$, while $\mathrm{Mn}$ has high loadings in the third principal component $(r=0.867)$. There are significant correlations between $\mathrm{Mo}, \mathrm{Cl}$ and $\mathrm{Co}$, and between $\mathrm{Mg}$ and $\mathrm{Mn}$.

PCA was also conducted on the heavy metal data, with varimax rotation. The variables are $\mathrm{As}, \mathrm{Cr}, \mathrm{Pb}, \mathrm{Hg}, \mathrm{Ni}$ and Se. The total variance showed that only one component with an initial Eigenvalue $>1.0$ (Table 8). This component was then rotated and the principal component accounted for $72.93 \%$ of variance. The rotated component matrix items and loadings are reported in Table 8b, with loadings $<0.30$ omitted to improve clarity. Results suggest that, in keeping with zero-order correlations, the rotated component increases with increasing $\mathrm{As}, \mathrm{Cr}, \mathrm{Pb}, \mathrm{Hg}, \mathrm{Ni}$ and $\mathrm{Se}$.
These elements have high positive loadings, with correlation coefficients of $\mathrm{r}=0.795,0.919,0.914,0.823,0.860$ and 0.804 , respectively. Therefore, strong correlations exist between the heavy metal concentrations.

One-way ANOVA was used to determine if the differences observed in the mean concentrations of the macronutrients are statistically significant. The significant differences for P, K, Ca and S are P $<0.001,<0.001,<0.01$ and $<0.001$, respectively (Table 9 ). Thus, differences in the concentrations of these macro-nutrients are significant. The exception is $\mathrm{Mg}(\mathrm{P}>0.05)$.

Table 6a. Total explained variance of the macro-nutrient data

\begin{tabular}{|c|c|c|c|c|c|c|}
\hline \multirow{2}{*}{$\begin{array}{c}\text { Com- } \\
\text { po- } \\
\text { nent }\end{array}$} & \multicolumn{3}{|c|}{ Initial Eigenvalues } & \multicolumn{3}{c|}{$\begin{array}{c}\text { Extraction Sums of } \\
\text { Squared Loadings }\end{array}$} \\
\cline { 2 - 7 } & Total & $\begin{array}{c}\text { \% of } \\
\text { Vari- } \\
\text { ance }\end{array}$ & $\begin{array}{c}\text { Cumula- } \\
\text { tive \% }\end{array}$ & Total & $\begin{array}{c}\% \text { of } \\
\text { Vari- } \\
\text { ance }\end{array}$ & $\begin{array}{c}\text { Cu- } \\
\text { mula- } \\
\text { tive \% }\end{array}$ \\
\hline 1 & 2.486 & 49.713 & 49.713 & 2.486 & 49.713 & 49.713 \\
\hline 2 & 0.973 & 19.464 & 69.178 & & & \\
\hline 3 & 0.713 & 14.252 & 83.430 & & & \\
\hline 4 & 0.495 & 9.890 & 93.321 & & & \\
\hline 5 & 0.334 & 6.679 & 100.000 & & & \\
\hline
\end{tabular}

Note: extraction method: principal component analysis.

Table 6b. Rotated component matrix for macro-nutrient data

\begin{tabular}{|l|c|}
\hline \multirow{2}{*}{} & Component \\
\cline { 2 - 2 } & 1 \\
\hline Magnesium & -0.733 \\
\hline Phosphorus & 0.440 \\
\hline Potassium & 0.765 \\
\hline Calcium & -0.800 \\
\hline Sulphur & 0.729 \\
\hline
\end{tabular}


Table 7a. Total explained variance of the micro-nutrient data

\begin{tabular}{|c|c|c|c|c|c|c|c|c|c|}
\hline \multirow{2}{*}{ Component } & \multicolumn{3}{|c|}{ Initial Eigenvalues } & \multicolumn{2}{|c|}{ Extraction Sums of Squared Loadings } & \multicolumn{3}{|c|}{ Rotation Sums of Squared Loadings } \\
\cline { 2 - 10 } & Total & $\begin{array}{c}\% \text { of Vari- } \\
\text { ance }\end{array}$ & $\begin{array}{c}\text { Cumulative } \\
\%\end{array}$ & Total & $\begin{array}{c}\% \text { of Vari- } \\
\text { ance }\end{array}$ & $\begin{array}{c}\text { Cumulative } \\
\%\end{array}$ & \multicolumn{2}{c|}{$\begin{array}{c}\text { Total } \\
\% \text { of Vari- } \\
\text { ance }\end{array}$} & $\begin{array}{c}\text { Cumulative } \\
\%\end{array}$ \\
\hline 1 & 2.703 & 38.620 & 38.620 & 2.703 & 38.620 & 38.620 & 2.578 & 36.835 & 36.835 \\
\hline 2 & 1.530 & 21.860 & 60.480 & 1.530 & 21.860 & 60.480 & 1.612 & 23.026 & 59.861 \\
\hline 3 & 1.093 & 15.619 & 76.098 & 1.093 & 15.619 & 76.098 & 1.137 & 16.237 & 76.098 \\
\hline 4 & 0.753 & 10.763 & 86.861 & & & & & & \\
\hline 5 & 0.497 & 7.094 & 93.955 & & & & & & \\
\hline 6 & 0.343 & 4.894 & 98.850 & & & & & & \\
\hline 7 & 0.081 & 1.150 & 100.000 & & & & & & \\
\hline
\end{tabular}

Note: extraction method: principal component analysis.

Table 7b. Rotated component matrix for micronutrient data

\begin{tabular}{|l|c|c|c|}
\hline \multirow{2}{*}{} & \multicolumn{2}{|c|}{ Component } \\
\cline { 2 - 4 } & 1 & 2 & 3 \\
\hline Manganese & 0.031 & -0.289 & 0.867 \\
\hline Iron & 0.951 & -0.024 & -0.141 \\
\hline Copper & 0.576 & -0.215 & -0.386 \\
\hline Zinc & 0.845 & -0.067 & 0.129 \\
\hline Molybdenum & 0.140 & 0.842 & 0.308 \\
\hline Chlorine & -0.602 & 0.507 & -0.241 \\
\hline Cobalt & 0.609 & 0.655 & 0.054 \\
\hline
\end{tabular}

Table 8a. Total explained variance of the heavy metal data

\begin{tabular}{|c|c|c|c|c|c|c|}
\hline \multirow{2}{*}{ Component } & \multicolumn{3}{|c|}{ Initial Eigenvalues } & \multicolumn{2}{c|}{ Extraction Sums of Squared Loadings } \\
\cline { 2 - 7 } & Total & \% of Variance & Cumulative \% & Total & \% of Variance & Cumulative \% \\
\hline 1 & 4.376 & 72.929 & 72.929 & 4.376 & 72.929 & 72.929 \\
\hline 2 & 0.974 & 16.235 & 89.164 & & & \\
\hline 3 & 0.415 & 6.912 & 96.076 & & & \\
\hline 4 & 0.155 & 2.590 & 98.666 & & & \\
\hline 5 & 0.078 & 1.295 & 99.961 & & & \\
\hline 6 & 0.002 & 0.039 & 100.000 & & & \\
\hline
\end{tabular}

Note: extraction method: principal component analysis.

Table 8 b. Rotated component matrix for the heavy metal data

\begin{tabular}{|l|c|}
\hline \multirow{2}{*}{} & Component \\
\cline { 2 - 2 } & 1 \\
\hline Arsenic & 0.795 \\
\hline Chromium & 0.919 \\
\hline Lead & 0.914 \\
\hline Mercury & 0.823 \\
\hline Nickel & 0.860 \\
\hline Selenium & 0.804 \\
\hline
\end{tabular}

ANOVA of micro-nutrient data shows highly significant differences (all P-values <0.001) in the mean concentrations of $\mathrm{Fe}, \mathrm{Zn}$ and Co (Table 10). However, the $\mathrm{P}$-values of $\mathrm{Mn}, \mathrm{Cu}$ and $\mathrm{Cl}$ are all $>0.05$. One-way ANOVA of the heavy metal data showed significant differences for As, Cr, Pb, Hg, Ni and Se ( $\mathrm{P}<0.001$ for all six metals) (Table 11). 
Table 9. ANOVA of the macro-nutrient data

\begin{tabular}{|c|c|c|c|c|c|c|c|}
\hline & & & $\begin{array}{l}\text { Sum of } \\
\text { Squares }\end{array}$ & d.f. & $\begin{array}{l}\text { Mean } \\
\text { Square }\end{array}$ & $\mathrm{F}$ & $\mathrm{P}$ \\
\hline \multirow[t]{3}{*}{ Magnesium } & Between Groups & (Combined) & 220.83 & 8 & 27.60 & 2.07 & 0.103 \\
\hline & \multicolumn{2}{|l|}{ Within Groups } & 213.33 & 16 & 13.33 & & \\
\hline & \multicolumn{2}{|l|}{ Total } & 434.16 & 24 & & & \\
\hline \multirow[t]{3}{*}{ Phosphorus } & Between Groups & (Combined) & 166.74 & 8 & 20.84 & 21.11 & $<0.001$ \\
\hline & \multicolumn{2}{|l|}{ Within Groups } & 15.80 & 16 & 0.99 & & \\
\hline & \multicolumn{2}{|l|}{ Total } & 182.54 & 24 & & & \\
\hline \multirow[t]{3}{*}{ Potassium } & Between Groups & (Combined) & 3959.86 & 8 & 494.98 & 15.13 & $<0.001$ \\
\hline & \multicolumn{2}{|l|}{ Within Groups } & 523.50 & 16 & 32.72 & & \\
\hline & \multicolumn{2}{|l|}{ Total } & 4483.36 & 24 & & & \\
\hline \multirow[t]{3}{*}{ Calcium } & Between Groups & (Combined) & 1151.33 & 8 & 143.92 & 4.12 & 0.008 \\
\hline & \multicolumn{2}{|l|}{ Within Groups } & 556.67 & 16 & 34.79 & & \\
\hline & \multicolumn{2}{|l|}{ Total } & 1708.00 & 24 & & & \\
\hline \multirow[t]{3}{*}{ Sulphur } & Between Groups & (Combined) & 30.50 & 8 & 3.81 & 8.13 & $<0.001$ \\
\hline & \multicolumn{2}{|l|}{ Within Groups } & 7.50 & 16 & 0.47 & & \\
\hline & \multicolumn{2}{|l|}{ Total } & 38.00 & 24 & & & \\
\hline
\end{tabular}

Table 10. ANOVA of the micro-nutrient data

\begin{tabular}{|c|c|c|c|c|c|c|c|}
\hline & & & $\begin{array}{l}\text { Sum of } \\
\text { Squares }\end{array}$ & d.f. & Mean Square & $\mathrm{F}$ & $\mathrm{P}$ \\
\hline \multirow[t]{3}{*}{ Manganese } & Between Groups & (Combined) & 1044262.48 & 8 & 130532.81 & 1.72 & 0.174 \\
\hline & \multicolumn{2}{|l|}{ Within Groups } & 1139824.93 & 15 & 75988.33 & & \\
\hline & \multicolumn{2}{|l|}{ Total } & 2184087.43 & 23 & & & \\
\hline \multirow[t]{3}{*}{ Iron } & Between Groups & (Combined) & 48.95 & 8 & 6.12 & 287.35 & $<0.001$ \\
\hline & \multicolumn{2}{|l|}{ Within Groups } & 0.32 & 15 & 0.02 & & \\
\hline & \multicolumn{2}{|l|}{ Total } & 49.27 & 23 & & & \\
\hline \multirow[t]{3}{*}{ Copper } & Between Groups & (Combined) & 0.02 & 8 & 0.003 & 2.25 & 0.084 \\
\hline & \multicolumn{2}{|l|}{ Within Groups } & 0.020 & 15 & 0.001 & & \\
\hline & \multicolumn{2}{|l|}{ Total } & 0.05 & 23 & & & \\
\hline \multirow[t]{3}{*}{ Zinc } & Between Groups & (Combined) & 0.04 & 8 & 0.005 & 82.01 & $<0.001$ \\
\hline & \multicolumn{2}{|l|}{ Within Groups } & 0.001 & 15 & 0.00 & & \\
\hline & \multicolumn{2}{|l|}{ Total } & 0.04 & 23 & & & \\
\hline \multirow[t]{3}{*}{ Molybdenum } & Between Groups & (Combined) & 0.00 & 8 & 0.00 & 1.24 & 0.341 \\
\hline & \multicolumn{2}{|l|}{ Within Groups } & 0.00 & 15 & 0.00 & & \\
\hline & \multicolumn{2}{|l|}{ Total } & 0.00 & 23 & & & \\
\hline \multirow[t]{3}{*}{ Chlorine } & Between Groups & (Combined) & 200.94 & 8 & 25.12 & 1.60 & 0.206 \\
\hline & \multicolumn{2}{|l|}{ Within Groups } & 235.32 & 15 & 15.67 & & \\
\hline & \multicolumn{2}{|l|}{ Total } & 436.28 & 23 & & & \\
\hline \multirow[t]{3}{*}{ Cobalt } & Between Groups & (Combined) & 0.21 & 8 & 0.03 & 208174.75 & $<0.001$ \\
\hline & \multicolumn{2}{|l|}{ Within Groups } & 0.001 & 15 & 0.00 & & \\
\hline & \multicolumn{2}{|l|}{ Total } & 0.21 & 23 & & & \\
\hline
\end{tabular}


Table 11. ANOVA of the heavy metal data

\begin{tabular}{|c|c|c|c|c|c|c|c|}
\hline & & & $\begin{array}{l}\text { Sum of } \\
\text { Squares }\end{array}$ & d.f. & Mean Square & $\mathrm{F}$ & $\mathrm{P}$ \\
\hline \multirow[t]{3}{*}{ Arsenic } & Between Groups & (Combined) & 0.000 & 8 & 0.00 & 6.06 & $<0.001$ \\
\hline & \multicolumn{2}{|l|}{ Within Groups } & 0.000 & 16 & 0.00 & & \\
\hline & \multicolumn{2}{|l|}{ Total } & 0.000 & 24 & & & \\
\hline \multirow[t]{3}{*}{ Chromium } & Between Groups & (Combined) & 0.001 & 8 & 0.00 & 15.85 & $<0.001$ \\
\hline & \multicolumn{2}{|l|}{ Within Groups } & 0.000 & 16 & 0.00 & & \\
\hline & \multicolumn{2}{|l|}{ Total } & 0.001 & 24 & & & \\
\hline \multirow[t]{3}{*}{ Lead } & Between Groups & (Combined) & 0.001 & 8 & 0.00 & 2825.78 & $<0.001$ \\
\hline & \multicolumn{2}{|l|}{ Within Groups } & 0.000 & 16 & 0.00 & & \\
\hline & \multicolumn{2}{|l|}{ Total } & 0.001 & 24 & & & \\
\hline \multirow[t]{3}{*}{ Mercury } & Between Groups & (Combined) & 0.000 & 8 & 0.00 & 1721.21 & $<0.001$ \\
\hline & \multicolumn{2}{|l|}{ Within Groups } & 0.000 & 16 & 0.00 & & \\
\hline & \multicolumn{2}{|l|}{ Total } & 0.000 & 24 & & & \\
\hline \multirow[t]{3}{*}{ Nickel } & Between Groups & (Combined) & 0.000 & 8 & 0.00 & 16.24 & $<0.001$ \\
\hline & \multicolumn{2}{|l|}{ Within Groups } & 0.000 & 16 & 0.00 & & \\
\hline & \multicolumn{2}{|l|}{ Total } & 0.000 & 24 & & & \\
\hline \multirow[t]{3}{*}{ Selenium } & Between Groups & (Combined) & 0.000 & 8 & 0.00 & 742.00 & $<0.001$ \\
\hline & \multicolumn{2}{|l|}{ Within Groups } & 0.000 & 16 & 0.00 & & \\
\hline & \multicolumn{2}{|l|}{ Total } & 0.000 & 24 & & & \\
\hline
\end{tabular}

\section{Summary and conclusions}

Geochemical characterization of banana, buriti palm, jute and coir fibres was conducted to determine their potential for elemental inputs into soil systems on decomposition. The fibres contained both macro- and micro-nutrients. Identified macro-nutrients include $\mathrm{Mg}, \mathrm{K}, \mathrm{P}, \mathrm{Ca}$ and $\mathrm{S}$. $\mathrm{K}$ concentrations were particularly high in banana-fibre samples, and thus biogeotextiles produced from them will potentially add K to soils (Marschner 1993). Ca concentrations were also especially high in banana-leaf fibres. Within the selected plant sample types, bananaleaf/stem proved to be the most effective plant fibre in terms of nutrient inputs to soil on decomposition, having the highest proportion of macro-nutrients. This study suggests that geochemical analysis can ascertain if plant fibres with potential for producing effective biogeotextiles can eventually add nutrients to soil systems. It can be concluded that:

1. Fe varied from $0.15 \%$ in banana-leaf/stem samples (Oleo) $-4.47 \%$ in jute-cloth (India), with a mean of $0.82 \%$. Similarly, Mn varied from $0.03 \%$ in banana-leaf/stem (Oleo)-1.89\% in banana-leaf/stem (Macaé), with a mean of $0.35 \%$.

2. $\mathrm{K}$ varied from $3.63 \%$ in jute-mats (India) $-50.73 \%$ in banana-leaf (São Romão), with a mean of $27.16 \%$. Similarly, Ca varied from $0.09 \%$ in banana-leaf (São Romão) - 37.0\% in banana-leaf/ stem (Oleo), with a mean of $10.49 \%$.

3. The fibre samples have high concentrations of the macro-elements $\mathrm{Mg}, \mathrm{P}, \mathrm{K}, \mathrm{Ca}$ and $\mathrm{S}$. $\mathrm{Cl}$ had the highest concentration of $17.11 \%$ (in banana-leaf/ stem from Oleo) compared with other micro-elements.

4. In terms of the macro-nutrient contents of the selected plant fibres (banana, buriti, jute and coir), banana-leaf/stem from Oleo had the highest concentration (73.0\%), while coir fibre from Brazil had the least (25.86\%). This suggests that banana-leaf geotextiles will add most nutrients to soil systems on decomposition.

5. In terms of overall nutrient content, the sequence was banana-leaf $>$ buriti palm-leaf $>$ jute $>$ coir.

6. Each of the investigated plant types (banana, buriti, jute and coir), if utilized as biogeotextiles, will add notable amounts of nutrients into soil on their decomposition.

7. None of fibres had notable concentrations of heavy metals and so do not pose any threat of heavy metal contamination of soils.

8. The mean heavy metal contents in different fibres and from different sources were significantly different.

9. This study recommends that geochemical analysis should ascertain the geochemical content of plant fibres prior to their use as biogeotextiles.

10. The general longevity of biogeotextiles exposed in field conditions varied from about three-months (humid tropical environment in Brazil) to two years (humid temperate environment in the British Isles). 


\section{Suggestions for further research}

The nutrient concentrations of potential biogeotextile merit further investigation, using more types of plant fibres. It must be emphasized that reported results relate to elemental totals (as analysed using XRF). A fuller study of nutrient exchanges between biogeotextiles and soil systems requires studies of labile nutrients extracted from biogeotextile fibres.

\section{Acknowledgements}

We gratefully acknowledge Hugo A.S. Loureiro (Rio de Janeiro) and David Townrow (Wolverhampton) for their help with sample preparation and analysis.

\section{References}

Adeitun, A. 2011. Evaluation of geochemical inputs from potential geotextile plant fibres (banana-leaf, banana-stem, banana-leaf stem, Miscanthus giganteus and Buriti palm): MSc thesis in Environmental Technology. The University of Wolverhampton. $70 \mathrm{p}$.

Álvarez-Mozos, J.; Abad, E.; Giménez, R.; Campo, M. A.; Goñi, M.; Arive, M.; Casalí, J.; Díez, J.; Diego, L. 2014. Evaluation of erosion control geotextiles on steep slopes, Part 1: Effects of runoff and soil loss, Catena 118: 168-178.

https://doi.org/10.1016/j.catena.2013.05.018

Bakker, R. R.; Elbersen, H. W. 2005. Managing ash content and quality in herbaceous biomass: an analysis from plant to product, in $14^{\text {th }}$ European Biomass Conference, 2005, Paris, France, 210-213.

Bhattacharyya, R.; Fullen, M. A.; Booth, C. A. 2011b. Using palm-mat geotextiles on an arable soil for water erosion control in the United Kingdom, Earth Surface Processes and Landforms 36: 933-945. https://doi.org/10.1002/esp.2123

Bhattacharyya, R.; Fullen, M. A.; Booth, C. A.; Kertész, A.; Tóth, A.; Szalai, Z.; Jakab, G.; Kozma, K.; Jankauskas, B.; Jankauskiene, G.; Bühmann, C.; Paterson, G.; Mulibana, E.; Nell, J. P.; Van der Merwe, G. M. E.; Guerra, A. J. T.; Mendonça, J. K. S.; Guerra, T. T.; Sathler, R.; Bezerra, J. F. R.; Peres, S. M.; Yi, Z.; Li, Y. M.; Panomtaranichagul, M.; Peukrai, S.; Thu, D. C.; Cuong, T. H.; Toan, T. T. 2011a. Effectiveness of biological geotextiles for soil and water conservation in different agro-environments, Land Degradation and Development 22: 495-504. https://doi.org/10.1002/ldr.1097

Bhattacharyya, R.; Fullen, M. A.; Booth, C. A.; Smets, T.; Poesen, J.; Black, A. 2011c. Using palm-mat geotextiles for soil conservation: Effects on soil properties, Catena 84: 99-107. https://doi.org/10.1016/j.catena.2010.10.003

Bhattacharyya, R.; Fullen, M. A.; Davies, K.; Booth, C. A. 2010a. Use of palm-mat geotextiles for rain splash erosion control, Geomorphology 119: 52-61.

https://doi.org/10.1016/j.geomorph.2010.02.018

Bhattacharyya, R.; Smets, T.; Fullen, M. A.; Poesen, J.; Booth, C. A. 2010b. Effectiveness of geotextiles in reducing runoff and soil loss: a synthesis, Catena 81: 184-195. https://doi.org/10.1016/j.catena.2010.03.003

Carvalho, J. L. N.; Raucci, G. S.; Cerri, C. E. P.; Bernoux, M.; Feigl, B. J.; Wruck, F. J.; Cerri, C. C. 2010. Impact of pasture, agriculture and crop-livestock systems on soil C stocks in Brazil, Soil \& Till Research 110: 175-186. https://doi.org/10.1016/j.still.2010.07.011
Chen, S. C.; Chang, K. T.; Wang, S. H.; Lin, J. Y. 2011. The efficiency of artificial materials used for erosion control on steep slopes, Environmental Earth Sciences 62: 197-206.

https://doi.org/10.1007/s12665-010-0514-6

Davies, K. 2000. An evaluation of the effectiveness of palm-mat geotextiles on the conservation of loamy soils of the Bridgenorth series: BSc Dissertation (unpublished). The University of Wolverhampton, UK, 18-20.

FAO. 2017. Dimensions of need- an atlas of food and agriculture corporate document repository; a report of the food and agricultural organization [online], [cited 28 September 2017]. Available from Internet: www.fao.org/documents/en/detail/20536

Fullen, M. A.; Booth, C. A.; Panomtaranichagul, M.; Subedi, M.; Li, Y. M. 2011a. Agro-environmental lessons from the 'Sustainable Highland Agriculture in South-East Asia' (SHASEA) Project, Journal of Environmental Engineering and Landscape Management 19(1): 101-113. https://doi.org/10.3846/16486897.2011.557476

Fullen, M. A.; Subedi, M.; Booth, C. A.; Sarsby, R. W.; Davies, K.; Bhattacharyya, R.; Kugan, R.; Luckhurst, D. A.; Chan, K.; Black, A. W.; Townrow, D.; James, T.; Poesen, J.; Smets, T.; Kertész, A.; Tóth, A.; Szalai, Z.; Jakab, G., Jankauskas, B.; Jankauskiene, G.; Bühmann, C. B. U.; Paterson, G.; Mulibana, E.; Nell, J. P.; Van der Merwe, G. M. E.; Guerra, A. J. T.; Mendonça, J. K. S.; Guerra, T. T.; Sathler, R.; Bezerra, A. J. T.; Peres, S. M.; Zheng, Y.; Li, Y. M.; Li, T.; Panomtaranichagul, M.; Peukrai, S.; Thu, D. C.; Cuong, T. H.; Toan, T. T.; Jonsyn-Ellis, F.; Sylva, J. Z.; Cole, A.; Mulholland, B.; Dearlove, M.; Corkill, C.; Tomlinson, P. 2011b. Utilizing biological geotextiles: Introduction to the BORASSUS Project and global perspectives, Land Degradation and Development 22: 453-462. https://doi.org/10.1002/ldr.1105

Guerra, A. J. T.; Bezerra, J. F. R.; Lima, L. D. M.; Mendonça, J. K. S.; Guerra, T. T.; Buhmann, C.; Paterson, D. G.; Pienaar, G.; Nell, J. P.; Mulibana, N. E.; Van Deventer, P. W.; Fullen, M. A. 2010. Land rehabilitation with the use of biological geotextiles in two different countries, Sociedade and Natureza, Uberlandia 22(3): 413-446.

https://doi.org/10.1590/S1982-45132010000300002

Guerra, A. J. T.; Fullen, M. A.; Jorge, M. C. O.; Bezerra, J. F. R.; Shokr, M. S. 2017. Slope processes, mass movement and soil erosion: a review, Pedosphere 27: 27-41.

https://doi.org/10.1016/S1002-0160(17)60294-7

Guerra, A. J. T.; Fullen, M. A.; Jorge, M. C. O.; Alexandre, S. T. 2014. Soil erosion and conservation in Brazil, Anuário do Instituto de Geociências (UFRJ) 37: 81-91.

https://doi.org/10.11137/2014_1_81_91

Guerra, A. J. T.; Bezerra, J. F. R.; Fullen, M. A.; Mendonça, J. K. S.; Jorge, M. C. O. 2015. The effects of biological geotextiles on gully stabilization in São Luís, Brazil, Natural Hazards 75: 2625-2636. https://doi.org/10.1007/s11069-014-1449-0

Jadia, C. D.; Fulekar, M. H. 2009. Phytoremediation of heavy metals: recent techniques, African Journal of Biotechnology 8(6): 921-928.

Jakab, G.; Szalai, Z.; Kertész, Á.; Tóth, A.; Madarász, B.; Szabó, S. 2012. Biological geotextiles against soil degradation under subhumid climate: a case study, Carpathathian Journal of Earth and Environmental Sciences 7(2): 125-134.

Jankauskas, B.; Jankauskiene, G.; Fullen, M. A. 2012. A field experiment on the use of biogeotextiles for the conservation of sand-dunes of the Baltic coast in Lithuania, Hungarian Geographical Bulletin 61(1): 3-17.

Jarašiūnas, G.; Kinderienė, I. 2016. Impact of agro-environmental systems on soil erosion processes and soil properties on 
hilly landscape in Western Lithuania, Journal of Environmental Engineering and Landscape Management 24(1): 60-69. https://doi.org/10.3846/16486897.2015.1054289

Jorge, M. C. O.; Guerra, A. J. T.; Fullen, M. A. 2016. Geotourism, geodiversity and geo-conservation in Ubatuba Municipality, São Paulo State, Brazil, Geography Review 29: 23-29.

Kaniu, M. I.; Angeyo, K. H.; Mwala, A. K.; Mangala, M. J. 2012. Direct rapid analysis of trace bioavailable soil macronutrients by chemometrics-assisted energy, dispersive X-ray fluorescence and scattering spectrometry, Analytica Chimica Acta 729: 21-25. https://doi.org/10.1016/j.aca.2012.04.007

Kertész, A.; Szalai, Z.; Jakab, G.; Tóth, A.; Szabo, S.; Madarasz, B.; Janskauskas, B.; Guerra, A.; Bezerra, J. F. R.; Panomtaranichagul, M.; Chau Thu, D.; Zheng, Y. 2011. Biological geotextiles as tools for soil moisture conservation, Land Degradation and Development 22: 472-479. https://doi.org/10.1002/ldr.1098

Marschner, H. 1993. Mineral nutrition of higher plants. 2nd ed. London: Academic Press.

Methacanon, P.; Weerawatsophon, U.; Sumransin, N.; Prahsarn, C.; Bergado, D. T. 2010. Properties and potential application of the selected natural fibers as limited life geotextiles, Carbohydrate Polymers 82(4): 1090-1096. https://doi.org/10.1016/j.carbpol.2010.06.036

Paterson, D. G.; Bühmann, C.; Pienaar, G. M. E.; Barnard, R. O. 2011. Beneficial effect of palm geotextiles on interrill erosion in South African soils and mine dam tailings: a rainfall simulator study, South African Journal of Plant \& Soil 28: 181-189.

Rickson, R. J. 2006. Controlling sediment at source: an evaluation of erosion control geotextiles, Earth Surface Processes and Landforms 31: 550-560. https://doi.org/10.1002/esp.1368

Saha, P.; Roy, D.; Manna, S.; Adhikari, B.; Sen, R.; Roy, S. 2012. Durability of transesterified jute geotextiles, Geotextile and Geomembranes 35: 69-75. https://doi.org/10.1016/j.geotexmem.2012.07.003

Saha, P.; Manna, S.; Roy, D.; Kim, M. Ch.; Chowdhury, S.; De, S.; Sen, R.; Adhikari, B.; Kim, J. K. 2014. Effect of photodegradation of lignocellulosic fibers transesterified with vegetable oil, Fibers and Polymers 15(11): 2345-2354. https://doi.org/10.1007/s12221-014-2345-7

Saha, P.; Roy, D.; Manna, S. 2015. Biodegradation of chemically modified lignocellulosic sisal fibers: study of the mechanism for enzymatic degradation of cellulose, e-Polymers 15(3): 185-194.
Shepherd, A. P. 2012. An agro-environmental analysis of Hanover Parish, Jamaica: Unpublished MSc Thesis in Environmental Management. The University of Wolverhampton, UK. 54 p.

Shirazi, S. M.; Adham, M. D. I.; Othman, F.; Zardari, N. H.; Ismail, Z. 2016. Runoff trend and potentiality in Melaka Tengah catchment of Malaysia using SCS-CN and statistical technique, Journal of Environmental Engineering and Landscape Management 24(4): 269-277. https://doi.org/10.3846/16486897.2016.1184153

Shokr, M. S.; El Baroudy, A. A.; Fullen, M. A.; El-Beshbeshy, T. R.; Ali, R. R.; Elhalim, A.; Guerra, A. J. T.; Jorge, M. C. O. 2016. Mapping of heavy metal contamination in alluvial soils of the Middle Nile Delta of Egypt, Journal of Environmental Engineering and Landscape Management 24(3): 218-231. https://doi.org/10.3846/16486897.2016.1184152

Smets, T.; Poesen, J.; Bhattacharyya, R.; Fullen, M. A.; Subedi, M.; Booth, C. A.; Kertész, A.; Szalai, Z.; Tóth, A.; Jankauskas, B.; Jankauskiene, G.; Guerra, A.; Bezerra, J. F. R.; Zheng, Y.; Panomtaranichagul, M.; Bühmann, C.; Paterson, D. G. 2011. Evaluation of biological geotextiles for reducing runoff and soil loss under various environmental conditions using laboratory and field plot data, Land Degradation and Development 22: 480-494. https://doi.org/10.1002/ldr.1095

Stanjek, H.; Hausler, W. 2004. Basics of X-ray diffraction, Hyperfine Interactions 154(1): 107-119. https://doi.org/10.1023/B:HYPE.0000032028.60546.38

Sumi, S.; Unnikrishnan, N.; Mattew, L. 2016. Surface modification of coir fires for extended hydrophobicity and anti-microbial property for possile geotextile application, Journal of Natural Fibres 14(3): 335-345. https://doi.org/10.1080/15440478.2016.1209714

Tapobrata, S. 2017. Jute geotextiles and their applications in civil engineering (Developments in Geotechnical Engineering). Springer Science and Business Media. Singapore, 216.

Thomsen, V. B. E.; Schatzlein, D. 2002. X-ray fluorescence spectrometry, Advanced Materials and Processes 160(8): 41-43.

Vasarevičius, S.; Skripkiūnas, G.; Danila, V. 2016. Experimental research into leaching of metals from immobilized CIS solar module waste, Journal of Environmental Engineering and Landscape Management 24(4): 269-277. https://doi.org/10.3846/16486897.2016.1198262 